\title{
BEHAVIORISTIK DALAM PEMBELAJARAN: TINJAUAN PENDIDIKAN ISLAM
}

\section{BEHAVIORISTIC IN LEARNING: A REVIEW OF ISLAMIC EDUCATION}

\author{
Eka Damayanti1), Arifuddin Siraj'), Rosmini ${ }^{3}$, Ramli4) \\ 1,2,3)Universitas Islam Negeri Alauddin Makassar, 4)Institute Agama Islam Negeri Parepare \\ eka.damayanti@uin-alauddin.ac.id ${ }^{1}$, ${\text { arifuddin.siraj@uin-alauddin.ac.id }{ }^{2} \text {, }}^{2}$ \\ rosminiamin72@gmail.com ${ }^{3}$,, ramli@iainpare.ac.id ${ }^{4}$
}

\begin{abstract}
Abstrak
Tulisan ini bertujuan mendeskripsikan teori pembentukan perilaku belajar behavioristik dalam dunia pendidikan dan tinjauannya dalam perspektif pendidikan Islam. Penelitian ini merupakan penelitian studi kepustakaan (library research) dengan menggunakan sumber data utama yakni jurnal dan buku referensi sesuai dengan fokus kajian penelitian. Data dianalisis menggunakan content analysis. Hasil penelitian menunjukkan adanya relevansi antara teori belajar behaviorisme dengan konsep pendidikan Islam. Dalam konsep pendidikan Islam juga dilakukan conditioning, repetition, dan reinforcement. Namun perbedaannya adalah dalam konsep behaviorisme Islam tetap berdasarkan prinsip ketauhidan yakni kehendak dan persetujuan Allah. Seberapa kuatpun manusia berusaha membuat pengkondisian namun tergantung dari kehendak Allah SWT.
\end{abstract}

Kata Kunci: behavioristik, pembelajaran, pendidikan Islam

\begin{abstract}
This essay aims to describe the theory of behavioristic learning formation in education and its review from Islamic education's view. This research was library research using journals and reference books that focus on the research study. Data were analyzed using content analysis. The results of the study showed a relevance between behaviorism learning theory and the concept of Islamic education. Conditioning, repetition and reinforcement are all used in Islamic education. The Islamic behaviorism concept, on the other hand, is founded on monotheism, namely Allah's will and approval. No matter how firm humans make the conditioning, it depends on Allah SWT's will.
\end{abstract}

Keywords: behaviorism, learning, Islamic education

How to Cite: Damayanti, E., Siraj, A., \& Rosmini. (2021). Behavioristik dalam pembelajaran: tinjauan pendidikan Islam. Al asma: Journal of Islamic Education, 3(1), 121-133.

\section{PENDAHULUAN}

Teori belajar behavioral merupakan teori yang sudah lama terbentuk. Meskipun banyak kritik yang ditujukan pada teori behavioristik ini karena teorinya lahir dengan menggunakan percobaan menggunakan binatang, misalnya Thorndike menggunakan Kucing, Pavlov menggunakan Anjing, Hull menggunakan Tikus, Guthrie menggunakan Kucing, Skinner menggunakan Tikus, namun faktanya teori ini tidak tenggelam dan bahkan menjadi dasar dalam pembentukan teori belajar modern.

Mahzab dalam psikologi memandang manusia dengan cara yang berbeda-beda. Terdapat 3 mahzab yang sangat berpengaruh, yakni psikoanalisis, behavioristik dan 
humanistik. Proses pembentukan perilaku manusia juga berbeda-beda berdasarkan perspektif mahzab yang digunakan. Misalnya dalam pandangan psikoanalisis memandang perilaku manusia itu terbentuk karena alam bawah sadarnya yang terbentuk berdasarkan pengalaman masa lalu individu tersebut. Jadi dalam pandangan psikoanalisis, manusia sangat dipengaruhi oleh masa lalu. Pandangan tersebut bertolak belakang dengan perspektif mahzab humanistik yang memandang perilaku manusia terbentuk karena adanya dorongan untuk aktualisasi diri. Jadi dalam mahzab humanistik lebih menekankan pada motivasi, cita-cita atau masa yang akan datang dari diri individu.

Pembentukan perilaku pada pendekatan behavioral menekankan pada masa sekarang atau saat ini. Segala hal yang individu terima dari lingkungannya dapat menjadi rangsangan atau stimulus untuk berperilaku atau berespon. Begitu pula dalam belajar, peserta didik dinilai dapat membentuk perilaku belajarnya berdasarkan stimulus yang diberikan dari lingkungan belajarnya.

Teori behavioristik lahir berdasarkan studi sistematik menggunakan eksperimen untuk memahami bagaimana manusia dan binatang belajar. Teknik-teknik yang digunakan seperti yang digunakan untuk percobaan ilmu pengetahuan alam. Slavin (2008) memaparkan eksperimen itu dimulai dilakukan Ivan Pavlov lalu Edward Thorndike kemudian diikuti B.F. Skinner. Skinner dalam Uno (2008) tetap memilih menggunakan hewan sebagai subjek dalam eksperimennya sebab mempercayai bahwa ada kesamaan antara prinsip tingkah laku hewan dan penerapannya terdapat hubungan yang nyata.

Kehadiran ketiga ilmuwan tersebut sangat mempengaruhi dunia pendidikan. Meskipun banyak kritikan tentang teori behavioristik ini, namun tetap perlu dipelajari untuk memahami berbagai perspektif dalam memandang perilaku belajar. Oleh karena itu, artikel ini dibuat dengan dasar untuk mengetahui lebih jelas dan lebih rinci gambaran teori pembentukan perilaku belajar dalam dunia pendidikan yang diuraikan menjadi beberapa bagian dari jawaban rumusan masalah: (1) Seperti apa konsep behavioristik dari beberapa tokoh?; (2) Seperti apa analisis perilaku terapan dalam pendidikan?; dan (3) Bagaimana relevansi teori behavioristik dengan pendidikan Islam?

\section{METODE PENELITIAN}

Artikel ini disusun menggunakan pendekatan penelitian kualitatif jenis penelitian kepustakaan (library research) yang fokus teori pembentukan perilaku belajar behvioristik dalam dunia pendidikan dan tinjauannya dalam perspektif pendidikan Islam. Teknik pengumpulan data menggunakan dokumentasi yang berasal dari jurnal dan buku referensi yang relevan dengan fokus kajian. Analisis data yang digunakan berupa analisis isi atau content analisys yang mengurai tentang fokus kajian.

\section{HASIL DAN PEMBAHASAN}

\section{Teori Behaviorisme dari Berbagai Tokoh}

Terdapat tiga tokoh yakni Ivan Petrovich Pavlov, Edward Lee Thorndike, dan Burrhus Frederic Skinner yang paling berpengaruh dalam teori behaviorisme yang penulis akan paparkan mulai dari teori yang dilahirkan berdasarkan percobaan masing-masing tokoh, implikasi teori yang dilahirkan dalam bidang pendidikan, sampai pada kekurangan dan kelebihan teori yang dilahirkan. 


\section{Ivan Petrovich Pavlov (1849 - 1936)}

\section{Teori yang dilahirkan}

Ivan Petrovich Pavlov lahir di Rusia yang menjadi ahli fisiologi yang melahirkan teori terkenal dengan nama Classical Conditioning Theory. Pavlov melahirkan teorinya berdasarkan eksperimen pada Anjing (Hergenhahn \& Olson, 2008). Pada eksperimen itu, Pavlov mengamati perilaku Anjing yang mula-mula mengeluarkan air liur (saliva) saat Anjing itu diberikan makan. Setelah percobaan tersebut, saat melihat makanan dan mendengar suara ilmuwan berjalan menuju laboratorium Anjing mulai mengeluarkan saliva. Pavlov mulai membunyikan garpu tala dan mencatat respon Anjing yang tidak mengeluarkan saliva. Pada percobaan tersebut, garpu tala adalah Stimulus Netral (SN) karena tidak membangkitkan saliva. Setelah itu Pavlov memberi makan Anjingnya dan responnya adalah saliva. Makanan ini disebut Unconditioned Stimulus (US) karena tanpa latihan sebelumnya atau conditioning yang dibutuhkan untuk membentuk hubungan alamiah antara makanan dan saliva. Saliva merupakan unconditioned response (UR) yang dapat timbul dengan sendirinya. Respon saliva setelah bunyi sekarang menjadi sebuah Conditioned Response (CR) (Woolfolk, 2009).

\section{Pavlov's Classic Experiment}

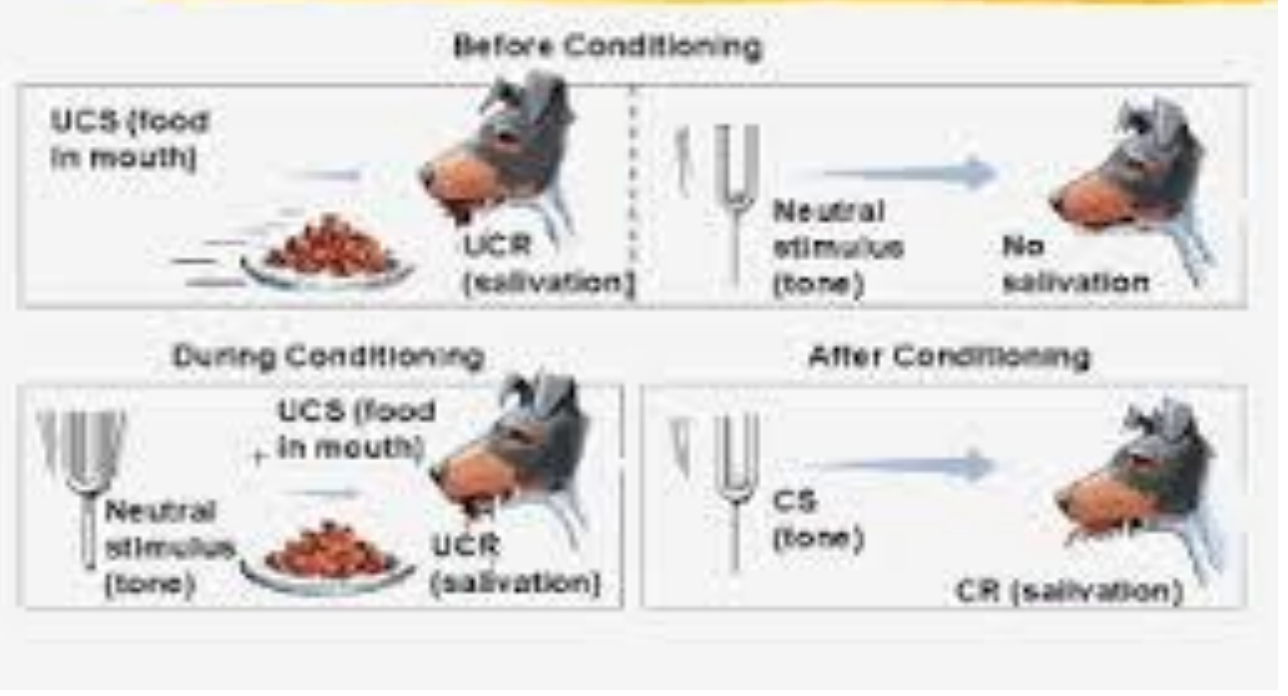

Gambar 1. Percobaan Pavlov

Sumber: docplayer.info

Teori ini memandang bahwa belajar merupakan perubahan perilaku. Teori ini dikembangkan melalui observasi terhadap perilaku belajar yang tampak atau disebut observable behavior (Herpratiwi, 2016). Teori classic conditioning (pengkondisian klasik) merupakan proses yang dilahirkan Pavlov melalui percobaan terhadap Anjing. Proses eksperimennya berlangsung dengan cara perangsang asli dan netral dipasangkan dengan stimulus bersyarat berulang-ulang sehingga memunculkan reaksi yang diinginkan (Molli \& Nini, 2020). Percobaan dari eksperimen Pavlov dapat disimpulkan apabila suatu 
stimulus yang dokondisikan (CS) selalu disertai dengan stimulus penguat (US), maka stimulus yang dikondisikan tadi (CS) cepat atau lambat akhirnya akan menimbulkan respon atau perubahan yang dikehendaki (CR) (Izzatur Rasuli, 2014).

Implikasi dalam pendidikan

Ivan Petrovich Pavlov melahirkan implementasi teori belajar dari teori classical conditioning-nya dalam pendidikan yaitu: (a) Memberikan suasana yang menyenangkan ketika memberikan tugas tugas belajar, agar peserta didik menghubungkan tugas itu sebagai sesuatu yang menyenangkan; (b) Membantu peserta didik dalam mengatasi kecemasannya dan membantu agar bisa keluar dari situasi-situasi yang menekan; (c) Membantu peserta didik dalam mengenal persamaan juga perbedaan akan berbagai situasi sehingga mammpu membuat perbedaan dan membuat generalisasi secara tepat (Isti'adah, 2020).

\section{Kelebihan dan kekurangan}

Menurut Lefudin (2017) kelebihan teori belajar Pavlov sebagai berikut: (1) Cocok diterapkan di kelas bawah; (2) Cocok untuk perolehan kemampuan yang membutuhkan praktik dan pembiasaan; dan (3) Metode efektif untuk menertibkan peserta didik. Adapun kelemahan teori belajar Pavlov sebagai berikut: (1) Pendidik sebagai sentral dan bersikap otoriter; (2) Komunikasi berlangsung satu arah; (3) Pendidik melatih dan menentukan apa yang harus dipelajari peserta didik; (4) Peserta didik dipandang pasif dan perlu motivasi dari luar; (5) Peserta didik hanya mendengarkan secara seksama penjelasan dari pendidik; dan (6) Hafalan dipandang sebagai cara belajar yang efektif (Lefudin, 2017). Hal yang paling dikhawatirkan jika pengkondisian klasik dilakukan secara terus-menerus, maka ditakutkan dapat membuat peserta didik akan memiliki rasa ketergantungan atas stimulus yang berasal dari luar dirinya (Isti'adah, 2020).

Teori yang Pavlov ungkapkan menurut penulis beberapa memang masih relevan untuk kondisi saat ini khususnya dalam pembiasaan dalam belajar. Meskipun dalam kodisi tertentu tidak tepat lagi mengingat orientasi pembelajaran lebih ditekankan pada kesadaran, bukan kebiasaan yang tidak disadari. Terlebih pada peran dominan pendidik yang untuk era saat ini sudah tidak relevan lagi karena akses sumber belajar sudah tidak terbatas ruang dan waktu.

\section{Edward Lee Thorndike (1871-1949)}

\section{Teori yang dilahirkan}

Thorndike yang merupakan psikolog asal Amerika Serikat dikenal sebagai ahli teori belajar terbesar sepanjang masa. Percobaannya menggunakan Ayam, Kucing, Tikus, Anjing, Ikan, Kera dan akhirnya manusia dewasa. Dari riset tersebut berhasil melahirkan buku Animal Intelligence. Teori yang dilahirkan Thorndike sebagai kombinasi dari asosianisme, darwinisme dan metode ilmiah (Hergenhahn \& Olson, 2008).

Thorndike melahirkan teori koneksionisme karena memandang belajar sebagai suatu kegiatan membentuk asosiasi atau connection antara kesan dari panca indera dengan kecenderungan bertindak. Bentuk paling dasar dari belajar yakni "trial and error learning" atau bisa juga disebut "selecting and connecting learning". Ide dasar tersebut didasari oleh eksperimen awalnya tentang perilaku Kucing yang dimasukkan dalam kerangkeng kecil dengan satu galah yang diletakkan ditengah dari rantai yang digantung dari atas. Kucing yang ada dalam kerangkeng memungkinkan melakukan 
segala upaya untuk bisa menekan galah agar pintu kerangkeng dapat terbuka. Setelah banyak percobaan, Kucing tersebut dapat mengenali dan segera mencakar galah tersebut (Hergenhahn \& Olson, 2008).

Referensi berbeda dinyatakan hal yang sama bahwa Thorndike melahirkan teori belajar "Connectionisme" karena dalam proses belajar terjadi mekanisme pembentukan koneksi-koneksi antara stimulus dengan respon. (Sagala, 2006). Menurut Thorndike kegiatan belajar dapat berjalan dengan baik saat ada motivasi. Sebagaimana pada percobaannya pada hewan yang sedang kelaparan, dimana hewan yang berada dalam kotak itu akan termotivasi untuk keluar mencari makanan (Erfan, 2018).

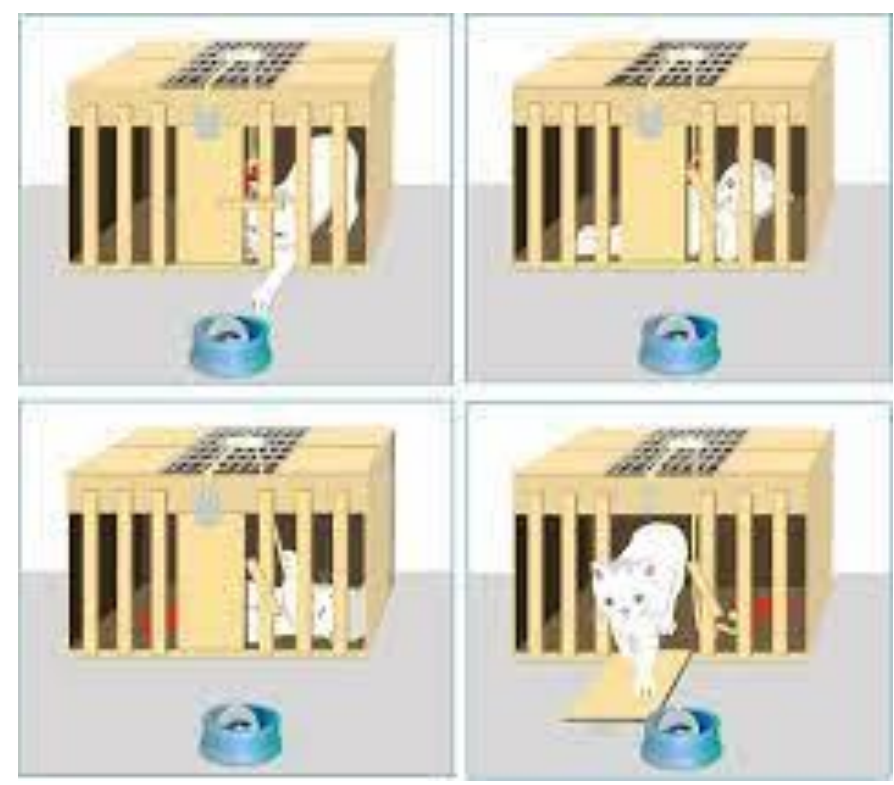

Gambar 2. Percobaan Thorndike

Sumber: pengetahuan blogger

\section{Implikasi dalam pendidikan}

Thorndike dalam Hergenhahn dan Olson (2008) melahirkan tiga teori hukum belajar, yakni: Pertama, hukum kesiapan (law of readiness), mengandung tiga bagian, yakni (a) ketika seseorang siap untuk melakukan suatu tindakan, maka melakukannya akan mendapatkan kepuasan; (b) ketika seseorang siap untuk melakukan suatu tindakan, maka tidak melakukannya akan menjengkelkan; dan (c) ketika seseorang belum siap untuk melakukan suatu tindakan, maka melakukannya akan menjengkelkan. Inti dari hukum kesiapan ini adalah belajar memerlukan kesiapan agar mendapatkan kepuasan dan menghindarkan dari kejengkelan. Kedua hukum latihan (law of exercise or repetition), yang terdiri dari dua bagian, yakni: (a) law of use (hukum penggunaan), hubungan antara stimulus dengan respons akan menguat saat keduanya dipakai; (b) law of disuse (hukum ketidakgunaan), hubungan antara situasi dan respon akan melemah apabila hubungan dihentikan. Inti dari hukum latihan ini menyatakan bahwa manusia belajar dengan berbuat dan lupa karena tidak berbuat. Jadi latihan akan memperkuat hubungan stimulus respon. Ketiga, hukum efek (law of effect), jika suatu stimulus menimbulkan respon yang pada gilirannya menimbulkan penguatan (reinforcement) maka hubungan stimulus respon akan menguat. Begitu pula sebaliknya jika stimulus menimbulkan respon yang 
berdampak menimbulkan hukuman maka hubungan stimulus respon akan melemah. Intinya pada hukum efek ini bahwa hubungan stimulus respon diperkuat bila disertai rasa senang.

Tiga hukum belajar di atas merupakan hukum primer, namun ada juga disebutkan sekunder dari Thorndike (Sagala, 2006) yang terdiri dari: (1) Law of Multiple Response, yaitu sesuatu yang dilakukan dengan variasi uji coba respon dalam menghadapi situasi problematis. Individu akan mencoba respon lain jika respon yang dilakukannya gagal sampai akhirnya salah satunya akan berhasil. Hal ini dikenal dengan proses belajar Trial and Error; (2) Law of Assimilation, merupakan hukum dimana seseorang akan mudah dalam menyesuaikan diri dengan situasi baru, asalkan situasi tersebut memiliki unsur yang bersamaan; (3) Law of Partial Activity, merupakan hukum dimana seseorang yang dapat bereaksi secara selektif terhadap kemungkinan yang ada pada situasi tertentu.

Hukum-hukum yang dikemukakan oleh Thorndike (Hamalik, 2010) itu lebih dilengkapi dengan prinsip-prinsip, sebagai berikut: (a) Peserta didik harus memiliki kemampuan multiple responses; (b) Sikap yang ditunjukkan peserta didik sangat penting saat belajar dibimbing; (c) Peserta didik harus memiliki associative shifting; (d) Peserta didik dapat membuat jawaban-jawaban terhadap situasi-situasi baru berdasar dari analogi dengan situasi terdahulu; (e) Peserta didik dapat memiliki kemampuan prepotent element.

\section{Kelebihan dan kekurangan}

Adapun kelemahan atau kekurangan dari teori Thorndike yaitu: (1) Teori koneksionisme bersifat hafalan atau mekanistis. Dimana anak didik hanya menguasai materi saja, sehingga banyak dari anak didik yang hanya menghafal materi pelajaran tapi tidak mengerti bagaimana pemakaiannya; (b) Teori ini bersifat teacher centered. Dimana guru yang aktif dalam memberi pelajaran pada anak didiknya, sementara anak didik hanya mendengarkan saja (Muktar, 2019).

Kelebihan teori Thorndike yaitu: (1) Sangat tepat dalam menumbuhkan keterampilan yang membutuhkan praktek dan pembiasaan yang di dalamnya berisi unsur spontanitas, kelenturan, reflek, kecepatan, daya tahan dan sebagainya; (b) Sangat cocok diterapkan dalam melatih anak yang masih memerlukan bantuan orang dewasa, suka pengulangan, suka meniru dan senang dengan bentuk-bentuk penghargaan langsung seperti diberi pujian dan sebagainya (Lefudin, 2017).

Teori yang Thorndike ungkapkan menurut penulis hampir sama dengan Pavlov yang lebih menekankan peran pendidik dalam mensetting pembelajaran yang saat ini sudah kurang relevan lagi dengan banyaknya sumber informasi diluar lingkungan sekolah. Namun yang tidak bisa ditinggal dari teori Thorndike ini yakni konsep koneksionismenya dan hokum kesiapan belajarnya. Bagaimanapun kondisinya, anak membutuhkan kesiapan belajar agar memudahkan pengetahuan dicerna.

\section{Burrhus Frederic Skinner (1904 - 1990)}

\section{Teori yang dilahirkan}

Burrhus Frederic Skinner terlahir di Pennsylvania Amerika melahirkan buku The Behavior of Organism dan berusaha menghubungkan temuan laboratorium dengan solusi yang dihadapi manusia. Karya-karyanya memicu perkembangan mesin pengajaran dan belajar terprogram (Hergenhahn \& Olson, 2008). Skinner mulai dengan keyakinan bahwa 
prinsip-prinsip dalam classical conditioning hanya menjelaskan sebagian kecil perilaku yang dipelajari. Namun banyak perilaku manusia yang bersifat operant (tindakan yang disengaja), bukan respondents (respon yang umumnya otomatis atau tidak disengaja yang ditimbulkan oleh stimuli tertentu). Classical conditioning hanya mendeskripsikan bilamana bila perilaku yang sudah ada dipasangkan dengan stimuli baru, namun tidak menjelaskan bagaimana perilaku operan baru diperoleh (Woolfolk, 2009).

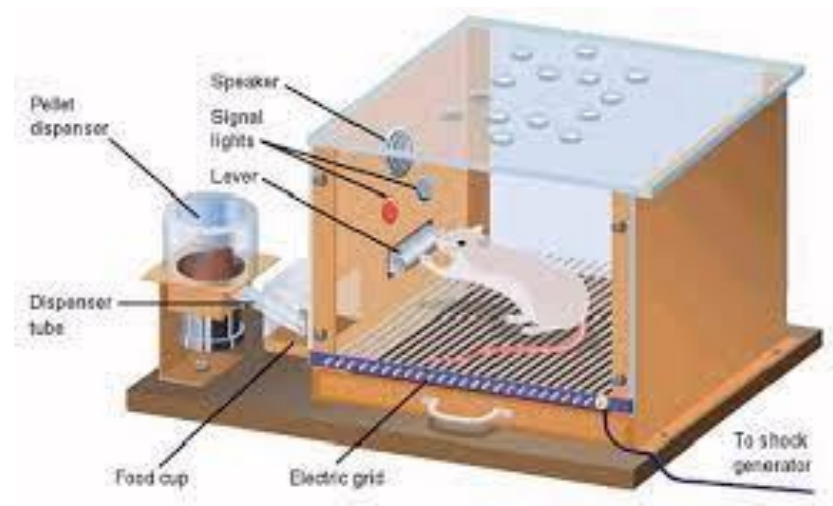

Gambar 3. Percobaan Skinner

Sumber: slidetodoc.com

Skinner memperkenalkan teori "operant conditioning" setelah melakukan sebuah eksperimen dengan meletakkan seekor Tikus yang lapar dalam sebuah kotak yang dikenal sebagai Kotak Skinner (Nahar, 2016). Skinner box ini merupakan pengembangan dari kotak teka teki yang dipakai oleh Thorndike. Kotak Skinner menggunakan lantai berkisi-kisi, cahaya, tuas/pengungkit, dan cawan makanan. Ketika Tikus menekan tuas, mekanisme pemberi makan akan aktif dan secuil makanan pun akan jatuh pada cawan makanan (Hergenhahn \& Olson, 2008).

Adapun prinsip umum dalam pengkondisian operan: (1) setiap respons yang diikuti dengan stimulus yang menguatkan cenderung akan diulang; dan (2) stimulus yang menguatkan adalah segala sesuatu yang memperbesar rata-rata terjadinya respon operan (Hergenhahn \& Olson, 2008). Skinner dalam teori pengkondisian operan melahirkan konsep reinforcement (penguatan) yang merupakan konsekuensi yang meningkatkan probabilitas bahwa suatu perilaku akan terjadi dan phunisment (hukuman) yang merupakan konsekuensi yang menurunkan probabilitas terjadinya suatu perilaku (Santrock, 2008).

Penerapan konsep hukuman dalam perilaku dianggap tidak efektif digunakan dalam jangka waktu yang panjang dan perilaku semula akan kembali sehingga kelihatan berhasil namun sebenarnya menghasilkan efek temporer saja. Selain itu (1) hukuman dapat menyebabkan efek samping berupa memburuknya kondisi emosional; (2) hukuman bukan menunjukkan apa yang seharusnya dilakukan namun hanya menunjukkan apa yang tidak boleh dilakukan; (3) Hukuman justru menjadi pembenaran terhadap tindakan menyakiti orang lain; (4) Anak akan merasa bahwa dia diperbolehkan lagi melakukan kesalahan saat berada pada situasi dimana perilaku yang dahulu dilakukan telah dihukum; (5) Hukuman dapat menyebabkan timbulkan perilaku agresi terhadap pelaku penghukum dan pihak lain; (6) Hukuman sering mengganti respon yang 
tidak diinginkan dengan respon yang tak diinginkan lainnya (Hergenhahn \& Olson, 2008).

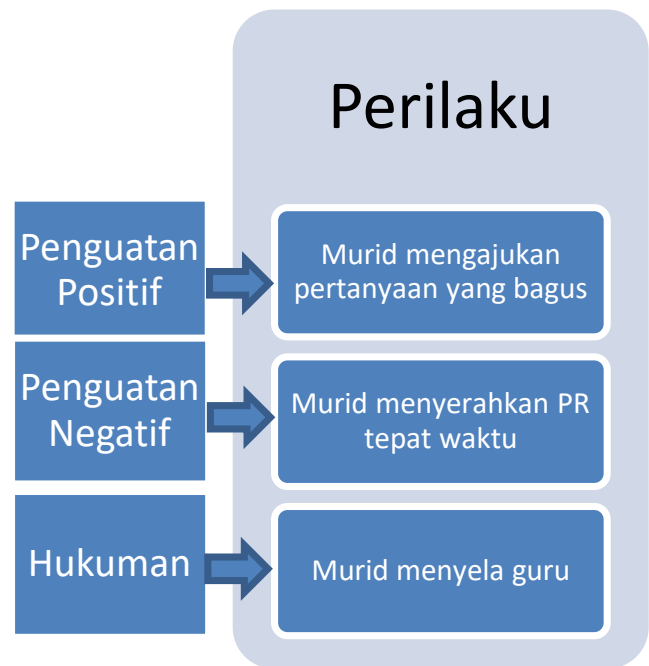

\section{Konsekuensi}

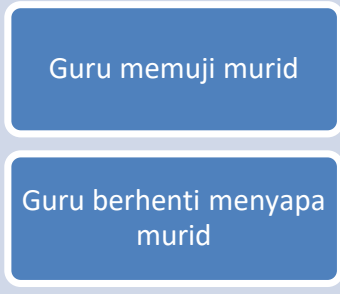

Guru menegur murid

\section{Perilaku ke depan}

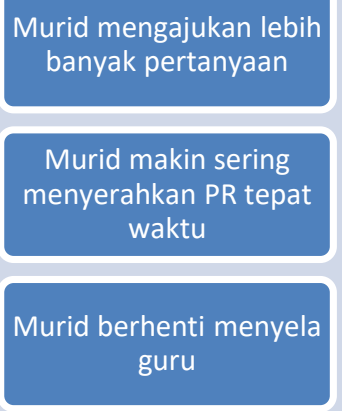

Gambar 4. Penguatan dan Hukuman

\section{Implikasi dalam pendidikan}

Skinner mampu menjelaskan suatu konsep belajar dengan sangat sederhana dan lebih komprehensif dan objektif (Andriani, 2015). Menurut Skinner (Hergenhahn \& Olson, 2008) belajar akan berlangsung sangat efektif apabila: (1) informasi yang akan dipelajari disajikan secara bertahap; (2) pembelajar segera diberi umpan balik (feedback) mengenai akurasi pembelajaran mereka agar tahu apakah sudah memahami informasi dengan benar atau tidak; (3) pembelajar mampu belajar dengan caranya sendiri; (4) Tujuan pembelajaran harus dispesifikkan secara behavioral terlebih dahulu agar guru tahu apa yang harus diajarkan; (5) Mengajarkan sesuatu harus dimulai dari hal yang sederhana karena hal yang kompleks berasal dari kumpulan hal-hal yang sederhana; (6) Penggunaan penguat sekunder/ekstrinsik sangat penting seperti pujian, penghargaan, penilaian, ekspresi, dll; (7) Hindari penggunaan teknik ceramah karena tidak bisa diatur jadwal penguatan; (8) Hindari pemberian hukuman

\section{Kelebihan dan kekurangan}

Teori yang dihasilkan Skinner dinilai mudah diterapkan dalam menangani berbagai masalah mulai dari hewan sampai modifikasi perilaku manusia. Menurut Verplanck bahwa penemuan Skinner bukan hanya sekedar detaik teoritis namun juga merepresentasikan re orientasi ke arah sains. Skinner berpegang teguh pada pendapatnya bahwa psikolog seharusnya tidak melakukan teorisasi khususnya pada aspek kognitif, mereka cukup memberikan penjelasan perilaku saja. Adapun kritik terhadap teori yang dihasilkan Skinner khususnya tentang "hukuman itu tidak efektif dan bahwa manusia tidak memiliki kehendak bebas sehingga manusia tidak bisa dituntut bertanggung jawab atas perilakunya" dinilai oleh Staddon sebagai sumber penyebab praktik pengasuhan yang menyimpang dan menyebabkan naiknya angka kejahatan dan tindakan melanggar hukum (Hergenhahn \& Olson, 2008).

Teori yang Skinner ungkapkan menurut penulis juga sama dengan teori yang diungkapkan Pavlov dan Thorndike, ada beberapa yang masih relevan. Pembiasaan operan masih dibutuhkan untuk kondisi saat ini khususnya dalam pembiasaan dalam belajar. Apalagi dalam masa pembelajaran daring, anak memerlukan stimulasi dari luar 
dirinya agar dapat belajar tanpa diawasi secara langsung oleh gurunya. Namun harus dikombinasikan dengan teknik lain agar tetap melihat potensi dasar peserta didik dan perlakuan operan yang dilakukan tidak menimbulkan ketergantungan sehingga lambat laut akan terbentuk kesadaran dari dalam diri peserta didik untuk belajar.

\section{Analisis Perilaku Terapan dalam Pendidikan}

Analisis perilaku terapan merupakan penerapan prinsip pengkondisian operan untuk mengubah perilaku manusia. Menurut Novi Irwan Nahar (2016) belajar behavioristik lebih memfokuskan untuk mengembangkan perilaku peserta didik kearah yang lebih baik. Smith, dkk (2009) memaparkan bahwa dalam teori behavioristik ini peserta didik difokuskan pada sebuah tujuan yang jelas dan bisa menanggapi secara otomatis segala isyarat dari tujuan pembelajaran.

Terdapat tiga penggunaan analisis perilaku dalam dunia pendidikan (Santrock, 2008; Woolfolk, 2009) dapat dijabarkan sebagai berikut: (1) Meningkatkan perilaku yang diinginkan seperti penggunaan pujian, prinsip premack (kegiatan yang lebih disukai dapat berfungsi sebagai reinforcer untuk kegiatan yang kurang disukai), dan menggunakan perjanjian; (2) Menggunakan dorongan (prompt berbentuk stimulus tambahan yang diberikan sebelum suatu respon dan meningkatnya kemungkinan respons itu akan terjadi) dan pembentukan (shaping berupa menguatkan setiap langkah kecil dalam kemajuan yang dicapai); dan (3) Mengurangi perilaku yang tidak diharapkan berupa reinforcement negative, satiasi (memaksa melanjutkan sampai kelelahan), reprimand (teguran), response cost (denda), isolasi sosial (time out).

Prayitno (2009) menjelaskan penguatan (reinforcement) diperuntukkan bagi tingkah laku yang baik dan dapat diterima yang memberikan nilai positif, berikut kategorinya: (1) Perilaku yang berkaitan dengan harkat dan martabat manusia yang meliputi hakikat manusia, dimensi kemanusiaan, dan pada daya yang seluruhnya normatif; (2) Perilaku yang berkaitan dengan nilai dan moral yang sumber utamanya pada ajaran agama, adat istiadat, ilmu, hukum dan kebiasaan dalam masyarakat; (3) Perilaku yang mendukung tugas perkembangan peserta didik agar maksimal ditahap berikutnya; (4) Perilaku yang berkaitan dengan kebutuhan dasar dan kebutuhan perkembangan; (5) Perilaku yang berkaitan dengan tujuan pendidikan/pembelajaran; (6) Perilaku yang muncul karena keuntungan dan dampak positif yang diperolehnya.

Terdapat 4 teorema pembelajaran dari Skinner dalam Uno (2008): (1) Peran pendidikan hakikatnya adalah menciptakan kondisi agar hanya tingkah laku yang diinginkan saja yang diberi penguatan; (2) Stimulus yang bersifat deskriptif hendaknya diberikan sebagai penunjang aktivitas belajar; (3) Pendidik harus membuat catatan kemajuan anak didiknya sehingga dapat melakukan penyesuaian program yang diperlukan; (4) Pendidik membuat rekomendasi tentang tugas mana yang harus dicoba dahulu dan bagaimana cara belajaranya serta hasil apa saja yang diharapkan. Keempat teorema ini menjadi dasar sejarah teknologi instruksional yang mengimplementasikan banyaknya alternatif teknologi pembelajaran lahir. Misalnya the Keller Plan dengan system pembelajaran personalisasi, Bloom dengan pendekatan pembelajaran tuntas (mastery learning), pendekatan audio-tutorial Postlethwait, pembelajaran dengan bantuan computer, dan lain sebagainya. 


\section{Relevansi Teori Behavioristik dengan Pendidikan Islam}

Konsep behavioristik telah ada dalam konsep pendidikan Islam sebelum teori behavioristik dilahirkan oleh ketiga tokoh di atas. Terdapat ayat dalam al-Qur'an yang menunjukkan lingkungan itu berpengaruh dalam pembentukan perilaku dan juga tentang pentingnya dilakukan pengkondisian dan pembiasaan. Misalnya "Dan perintahkanlah kepada keluargamu untuk melaksanakan shalat dan bersabarlah kamu dalam mengerjakannya...." (Thaha: 132).

Pada QS. Al Thaha 132 tersebut, Allah memerintahkan manusia untuk melaksanakan sholat dan disertai pesan agar bersabar dalam mengerjakan sholat. Pesan tersebut menandakan bahwa sholat itu merupakan mengondisian atau latihan yang harus dilakukan dalam proses yang panjang dan secara terus menerus jadi bukan hanya sekali saja, oleh karena itu perintah sholat disertai pesan untuk bersabar. Hal itu sesuai dengan teori behavioristik yang menekankan pada perilaku yang berulang agar terbentuk pembiasaan.

Persinggungan lain konsep beharioristik dengan Pendidikan Islam dapat ditemukan dalam konsep reward (penghargaan) dan punishment (hukuman). Dalam AlQur'an, konsep reward diungkapakan dengan term, tsawab, ajrun dan jazaaun. Budaiwi (2002) menjelaskan ketiga kata ini berkonotasi penghargaan atau apresiasi terhadap seseorang karena telah menyunmbangkan manfaat bagi orang lain dengan mengeluarkan tenaga, pikiran, waktu atau apapun yang dimilikinya untuk berbuat kebaikan untuk kehidupan Bersama. Dalam konteks Pendidikan, konotasi ini dimungkinkan karena orang yang terlibat dalam pembelajaran, pendidik maupun peserta didik keduanya telah berusaha berproses menjadi manusia yang dapat mendatangkan manfaat bukan hanya pada dirinya tapi juga bagi orang lain, sekarang dan di masa akan datang. Penghargaan Allah berupa pahala terhadap kebaikan yang dilakukan hamba-hamba-Nya sekecil apapun di antaranya dapat dilihat pada QS. Al-Nisa/4:40, QS al-Imran/3:148 dan QS alTaubah/9:120.

Penghargaan yang diberikan Allah atas usaha dan tanggungjawab yang dilakukan seorang hamba dalam menciptakan dan mendatangkan kebaikan. Seorang pembelajar yang menghadirkan prestasi belajar sekecil apapun prestasi itu, atau pembelajar yang melakukan perilaku baik dalam proses belajarnya selayaknya mendapat apresiasi atau penghargaan sebagai motivasi baginya untuk mengulang sikap positif yang dilakukannya atau sebagai motivasi baginya menciptakan prestasi berikutnya. Selain itu, penghargaan ini berfungsi untuk memotivasi pembelajar lain untuk melakukan kebaikan yang sama atau prestasi yang sama. Pemberian penghargaan terhadap peserta didik tidak hanya berupa materil, akan tetapi penghargaan itu juga dapat berupa dorongan moral dan spiritual agar terdapat keseimbangan orientasi dalam diri anak didik untuk menjadi manusia yang mampu berkompetisi dalam menghadapi situasi kompleks di masa yang akan datang. Dalam teori kondisional, hadiah dapat menjadi faktor utama dalam mendorong efektifitas proses belajar mengajar. Demikian juga dalam teori empiristik, hadiah dapat membantu anak berperilaku positif, terutama dalam proses belajar, sehingga pemberian penghargaan dalam bentuk hadiah dapat membantu memperkokoh karakter baik anak didik.

Adapun hukuman dalam Al-Qur'an diungkapkan dengan term iqab (QS alImran/3:11), azaab (QS al-Imran/3:77), dan rijz (QS al-A'raf/7:134). Ketiga term ini 
menunjuk makna hukuman. Hukuman merupakann konsekuensi dari sikap dan perilaku melanggar aturan. Dalam konteks Pendidikan Islam, hukuman bertujuan untuk memperbaiki karakter anak dari yang negatif menjadi positif. Pemberian hukuman tidak dimaksudkan sebagai aksi balas dendam, melainkan diberikan sebagai upaya perbaikan dan pengarahan kepada anak didik (Fahmi, 1979) dan sebagai bagian dari bentuk kasih sayang baginya agar menyadari pelanggaran yang telah dilakukannya dan menghindarkannya dari melakukan kesalahan berikutnya (Al-Abrasyi, 1975). Dalam konteks ini, hukuman dapat menjalankan fungsi sebagai instrument preventif terjadinya pelanggaran terahadap peraturan-peraturan yang telah disepakati. Pada satu sisi, hukuman selain dapat membelajarkan anak didik atas akibat kesalahan yang dilakukannya, pada sisi lain hukuman dalam melatih pendidik, orang tua atau guru untuk meningkatkan kasih sayangnya terhadap anak didik. Selain itu, menghindari terjadinya potensi kesalahan yang mungkin akan dilakukan anak didik lainnya. Pada intinya, pemberian hukuman dapat menyadarkan anak didik tentang resiko dan tanggungjawab, terutama dalam konteks pembelajaran.

Fera Andriani (2015) menyimpulkan dalam penelitiannya bahwa dalam pandangan Islam, bukan hanya lingkungan satu-satunya faktor yang mempengaruhi pendidikan akan tetapi faktor pembawaan juga turut andil sebagaimana dalam teori konvergensi yang menggabungkan antara faktor hereditas dan lingkungan. Bahkan dalam Islam, yang menjadi penentu akhir adalah iradah dan taufiq dari Allah SWT.

Evi Aeni Rufaedah (2018) dalam hasil penelitiannya menunjukkan bahwa teori behaviorisme dari Barat bersifat sekuler positivistik-materialistik. Hal itu disebabkan karena terjadi pembatasan hanya pada gejala belajar yang bersifat empiris-rasionalkuantitaif. Dengan demikian dalam teori behavioristik manusia menjadi tereduksi sebagai indiividu yang pagrmatis dan berorientasi pada materi sebagai stimulus. Padahal dalam Islam, teori belajarnya tidak hanya bersifat rasional-empiris, melainkan juga bersifat normatif-kualitatif.

Menurut Najati (dalam Rufaedah, 2018; Rusuli, 2014) terdapat teori belajar dalam Islam yang memiliki kemiripan dengan teori belajar behavioristik barat, yakni konsep belajar akhlaq yang menekankan pada pembentukan tingkah laku, yang terdiri dari tiga model; taqlid (imitasi), ta'wid (pembiasaan), dan tajribah wa khata' (trial and error). Zulhammi (2015) mengungkapkan ternyata masa 7 yakni masa memulai sebuah proses tadrib syarie yang juga dalam teori psikologi sangat banyak dibicarakan. Dalam ajaran Islam, Allah dan RasulNya menggunakan batas usia ini untuk membiasakan anak, misalnya sholat. Hal itu disebabkan masa ini masa paling bagus dalam membiasakan anak sebagai imitasi dari keteladanan yang dilakukan dari orangtuanya. Kalau dalam psikologi disebut sebagai learning readiness.

Yoga Anjas Pratama (2019) dalam penelitiannya menemukan adanya relevansi antara teori belajar behaviorisme terhadap pendidikan Islam karena teori belajar behaviorsime sejalan dengan ajaran agama Islam. Dalam konsep pendidikan Islam juga dilakukan Conditioning, repetition, dan reinforcement. Hanya saja menurut Fadhilah (2016) yang membedakan konsep behaviorisme barat dengan behaviorisme Islam adalah prinsip ketauhidan yakni kehendak dan persetujuan Allah. Seberapa kuatpun manusia berusaha membuat pengkondisian namun tergantung dari kehendak Allah SWT. 


\section{SIMPULAN}

Konsep dasar dalam teori behaviorisme yakni perilaku manusia dapat dibentuk dan dipelajari. Hal itu tergantung dari stimulus yang diterima. Terdapat tiga tokoh yang paling berpengaruh dalam teori behavioristik, yakni Ivan Petrovich Pavlov yang melahirkan teori Classical Conditioning, Edward Lee Thorndike yang melahirkan teori koneksionisme, dan Burrhus Frederic Skinner yang melahirkan teori operant conditioning.

Implikasi teori behavioristik dalam dunia pendidikan berupa (1) belajar memerlukan pembiasaan; (2) dalam pendidikan memerlukan reinforcement; (3) pendidikan berperan besar dalam memberikan stimulus pada anak. Adanya relevansi antara teori belajar behaviorisme dengan konsep pendidikan Islam. Dalam konsep pendidikan Islam juga dilakukan Conditioning, repetition, dan reinforcement. Namun perbedaannya adalah dalam konsep behaviorisme Islam tetap berdasarkan prinsip ketauhidan yakni kehendak dan persetujuan Allah. Seberapa kuatpun manusia berusaha membuat pengkondisian namun tergantung dari kehendak Allah SWT.

\section{DAFTAR PUSTAKA}

Al-Abrasyi, M. A. (1975). Tarbiyyah al-Islamiyah wa falsafatuha. Mesir: As- Syirkham.

Andriani, F. (2015). Teori belajar behavioristik dan pandangan islam tentang behavioristik. Syaikhuna: Jurnal Pendidikan Dan Pranata Islam, 6(2), 165-180. http://ejournal.kopertais4.or.id/madura/index.php/syaikhuna/article/view/1034

Budaiwi, A. A. (2002). Imbalan dan hukuman pengaruhnya bagi pendidikan anak. Jakarta: Gema Insani Press.

Erfan, Y. (2018). Teori-teori belajar matematika. In Diktat. Jember: Universitas Jember.

Fadhilah, N. (2016). Model bimbingan belajar behavioristik dan pandangannya dalam perspektif Islam. HIKMATUNA: Journal for Integrative Islamic Studies, 2(2), 235-260. https://doi.org/10.28918/hikmatuna.v2i2.961

Fahmi, A. H. (1979). Sejarah filsafat pendidikan Islam. Jakarta : Bulan Bintang.

Hamalik, O. (2010). Kurikiulum dan pembelajaran. Jakarta: Bumi Aksara.

Hergenhahn., B. R., \& Olson, M. H. (2008). Theories of learning. In Penerjemah: Tri Wibowo B. S. Jakarta: Kencana.

Herpratiwi. (2016). Teori belajar dan pembelajaran. Yogyakarta: Media Akademi.

Isti'adah, N. F. (2020). Teori-teori belajar dalam pendidikan. Bandung: Edu Publisher.

Lefudin. (2017). Belajar dan pembelajaran. Yogyakarta: Deepublish.

Molli, W., \& Nini, A. (2020). Teori belajar dan implikasinya dalam pembelajaran. Bandung: Edu Publisher.

Muktar, M. (2019). Pendidikan behavioristik dan aktualisasinya. Jurnal Pendidikan Islam, 1(1), 14-30. https://doi.org/10.29138/tabyin.v1i1.4

Nahar, N. I. (2016). Penerapan teori belajar behavioristik dalam proses pembelajaran. Nusantara: Jurnal Ilmu Pengetahuan Sosial, 1(1), 64-74. http://jurnal.umtapsel.ac.id/index.php/nusantara/article/view/94

Pratama, Y. A. (2019). Relevansi teori belajar behaviorisme terhadap pendidikan agama Islam. Al-Thariqah: Jurnal Pendidikan Agama Islam, 4(1), 38-49. https://doi.org/10.25299/al-thariqah.2019.vol4(1).2718 
Prayitno. (2009). Dasar teori dan praksis pendidikan. Jakarta: Grasindo.

Rufaedah, E. A. (2018). Teori belajar behavioristik menurut perspektif Islam. Risalah, Jurnal Pendidikan Dan Studi Islam, 4(1), 13-30. https://doi.org/doi.org/10.31943/jurnal_risalah.v4i1.60

Rusuli, I. (2014). Refleksi teori belajar behavioristik dalam perspektif Islam. Jurnal Perencanaan, 8(1), 38-54. https://doi.org/10.13170/jp.8.1.2042

Sagala, S. (2006). Konsep dan makna pembelajaran. Bandung: Alfabeta.

Santrock, J. W. (2008). Psikologi pendidikan. In Penerjemah: Tri Wibowo B. S. Jakarta: Kencana.

Slavin, R. E. (2008). Psikologi pendidikan. teori dan praktik. In Penerjemah: Drs. Marianto Samosir, S.H. Jakarta: PT Indeks.

Smith, M. K., \& Dkk. (2009). Teori pembelajaran dan pengajaran. Yogyakarta: Mirza Media Pustaka.

Uno, H. B. (2008). Orientasi baru dalam psikologi pembelajaran. Jakarta: Bumi Aksara.

Woolfolk, A. (2009). Educational psychology; active learning edition. In Penerjemah: Helly Prajitno Soetjipto dan Sri Mulyantini Soetjipto. Jakarta: Pustaka Pelajar.

Zulhammi. (2015). Teori belajar behavioristik dan humanistik dalam perspektif pendidikan Islam. Jurnal Darul Ilmi, 3(1), 105-127. http://repo.iainpadangsidimpuan.ac.id/364/1/356-1046-1-PB.pdf. 